\title{
POPULATION STRUCTURE AND BIOREPRODUCTION OF BIGEYE TUNA (Thunnus obesus) IN WESTERN PART OF SUMATERA AND SOUTHERN PART OF JAVA AND NUSA TENGGARA, INDIAN OCEAN
}

\author{
Ali Suman', Hari Eko Irianto ${ }^{2}$, Khairul Amri' ${ }^{1}$ Budi Nugraha ${ }^{3}$ and Gatut Bintoro 4 \\ ${ }^{1}$ Institute for Marine Fisheries, Muara Baru - Jakarta. Indonesia \\ ${ }^{2}$ Center for Fisheries Management and Conservation, Jakarta. Indonesia \\ ${ }^{3}$ Institute for Tuna Fisheries, Benoa, Bali-Indonesia \\ ${ }^{4}$ Faculty of Marine and Fisheries, Brawijaya University, Malang-Indonesia \\ Received; October 20-2014 Received in revised from December 06-2015; Accepted December 09-2015 \\ email: alisuman_62@yahoo.com
}

\begin{abstract}
Bigeye tuna is an important fish resource in the Indian Ocean. This species like other tuna species needs to be managed properly in both national and international levels. Therefore some data and information on population structure and bioreproduction are required for management purpose. The current research was conducted to identify the population structure and bioreproduction of bigeye tuna (Thunnus obesus) in west off Sumatera and south off Java and Nusa Tenggara of Indian Ocean where tuna fishing spots are important. This research was based on catch landed by fishermen from the Indian Ocean during 2010. Analysis of population structure was done using DNA genetic analyses and bioreproduction by using histology technique. Results show that the population structure of the bigeye tuna in the Indian Ocean consisted of two different sub populations namely sub population of west off Sumatra and sub population of south of Java and Nusa Tenggara waters. Most of catch (about 39\%) was categorized as immature fish (GI I). The immature fish was mostly found in west off Sumatera waters, meanwhile the catch in south off Java and Nusa Tenggara waters was mostly categorized as mature fish. This result may indicate that south off Java and Nusa Tenggara waters is a spawning ground of the bigeye tuna.
\end{abstract}

KEYWORDS: Histology, genetic, population structure, bigeye tuna, Indian Ocean

\section{INTRODUCTION}

Bigeye tuna (Thunnus obesus) is one of the important tuna resources in the Indian Ocean. This second biggest tuna species after madidihang (Thunnus alalunga) is predicted to live in all around the Indian Ocean and categorized as highly migratory species. The fishes migrates accross oceans from north part of the Indian Ocean, stretching in Indonesian waters from west off Sumatera to south off Java-Nusa Tenggara, which is the most potential spawning ground for the bigeye tuna resource (Nishikawa et al., 1985). Therefore, this area is very important for the tuna management purpose. In order to manage properly this high valuable fish both in regional and international levels, accurate information on population structure and reproduction aspect is needed.

Data of fish stock status in bigeye tuna such as population structure, and reproduction biology become more important in relation to other fish stocks in other places. In addition, the increase of exploitation level should needs to be monitored properly in order to identify the development and the change of biomass. Availability of these data analysized is usefull for
Indonesia to actively contribute information in managing in international level the tuna as a unity stock, especially in the Indian Ocean under an international organization of tuna (IOTC).

This paper describes population structure and reproductive biology of the bigeye tuna resource in west off Sumatera and south off Java and Nusa Tenggara waters of Indian Ocean. Hopely, the analysis disscussed in the current work could be used as valuable information for future stock assessment in achieving the good fishery management in the Indian Ocean.

\section{MATERIALS AND METHODS}

Primary data were collected in form on genetic base (mtDNA) obtained from histological analysis of 50 piece of fin and reproductive (maturity and Gonado Somatic Index). Samples of fish were collected on board during 2010 at two scatered groups of sampling location of Indian Ocean: (1) Group I (110.150 ${ }^{\circ}$ $120.475^{\circ} \mathrm{E}$ and $8.962^{\circ}-15.035^{\circ} \mathrm{S}$ ) and (2) Group II (97.209 $-100.503^{\circ} \mathrm{E}$ and $2.035^{\circ}-3.263^{\circ} \mathrm{S}$ ) (Figure 1). The fishes measured varied from 55 to $177 \mathrm{~cm}$ in fork length. 


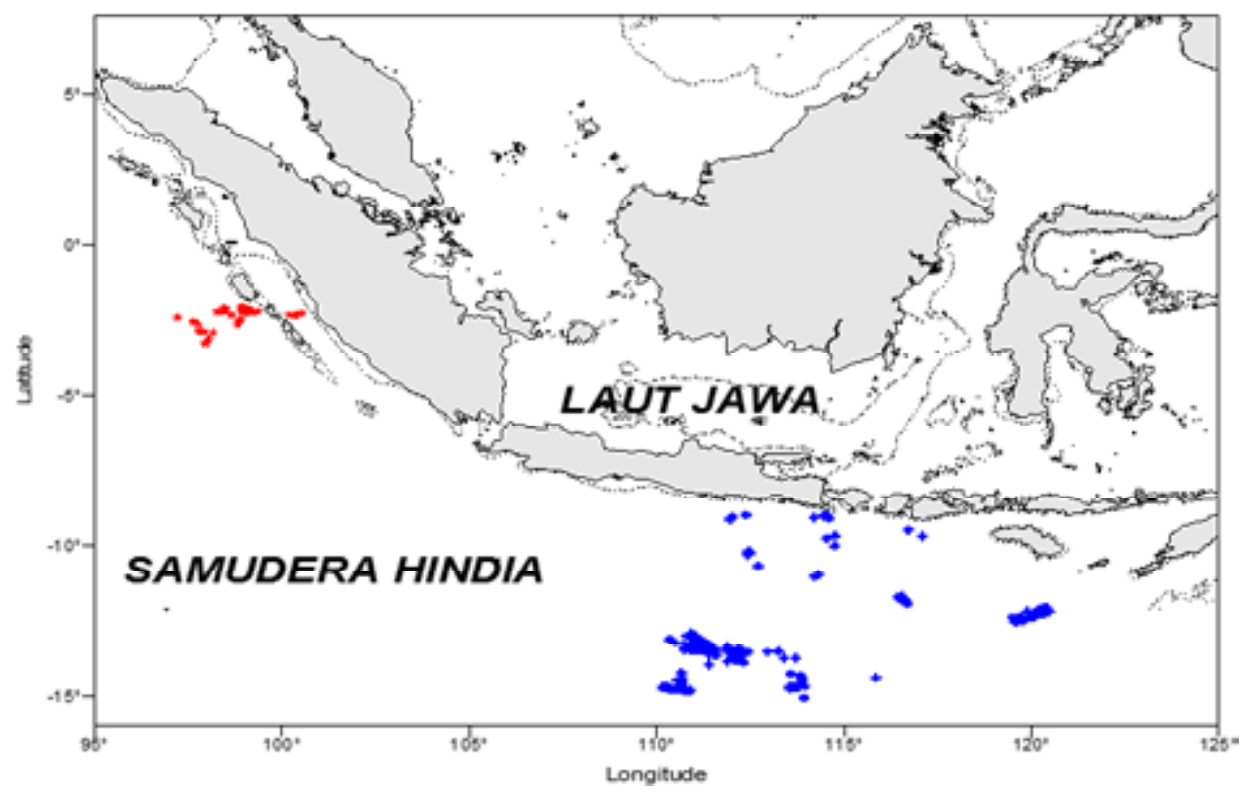

Figure 1. Two scatered groups of sampling location.

A piece of fin fish was taken to analysis the DNA was taken from histology of piece of fin using Wizard Genome DNA Purification kit (Promega). Primer Pro5 and primer 12SAR were used to amplify sequence of mitochondria D-loop using Polymerize Chain Reaction machine (PCR). Sequence of mtDNA was then restricted following endonuklease manual procedure. Electrophoresis process was run on agarose gel $2-3 \%$ in Tris-Boric-EDTA (TBE) buffer. The DNA separation was identified using UV illuminator visualized by polaroid film (Bremer, 1998).

Composite of haplotipe was analysed in order to define genetic parameter, population structure and phylogenic relationship each population. Genetic diversity degree was counted based on diversity index of haplotipe $(h)$ through frequency distribution of haplotipe (nukleomorf) with equation as follow:

$h=\frac{n}{n-1}\left(1-\sum_{i=1}^{n} X_{i}^{2}\right)$

where:

$\mathrm{h}=$ haplotipe diversity

$\mathrm{n}=$ number of group

$X_{1}=$ frequency of haplotipe sample $-i$

Genetic relationship of each population was decided based on genetic distance parameter (Nei, 1972) and statistic analysis of different restriction cite. The genetic distance was calculated according to eqution introduced by Nei (1978):

$$
D=-\ln \left[\frac{J_{a b}}{\left\{\left(J_{a} x J_{b}\right)^{0,5}\right\}}\right]
$$

where :

D : genetic distance

$\mathrm{J}_{a b} \quad$ : frequency of haplotipe of each place with same population.

$\mathrm{J}_{\mathrm{a}} \& \mathrm{~J}_{\mathrm{b}}$ : frequency of haplotipe population $\mathrm{A}$ and $\mathrm{B}$

Differential degree of moleculer haplotipe of each population was predicted by means of Analysis of Moleculer Varians (AMOVA) and trial mixed distance $(F s t)$ with equation as follow:

$F_{s t}=1-\left(\frac{H_{w}}{H_{b}}\right)$

where:

$\mathrm{F}_{\mathrm{st}}=$ diferential index

$\mathrm{H}_{w}^{\text {st }}=$ average difference of intra population

$\mathrm{H}_{\mathrm{b}}=$ average difference of among population

Relationship among population was illustrated in the form of clustering dendrogram of mark of genetic distance based on average distance method. Calculation was done using Tools for Population Genetics Analysis (TFPGA) introduced by Miller (1997).

Gonade preparation was done through $\mathrm{HE}$ (Haematoxylin and Eoxin) coloring technique toward piece of gonade histology sized $1 \times 1 \mathrm{~cm}$. Histological maturity stage was decided based on proportion of development of each oocyte. 
Fish maturity was decided based on Gonado Somatic Index (GSI) equation introduced by Effendie (1997):

$$
G S I=\frac{W g}{W} x 100 \%
$$

$$
\text { where: }
$$

$$
\begin{aligned}
& \mathrm{W}=\text { fish weight }(\mathrm{g}) \\
& \mathrm{Wg}=\text { gonade weight }(\mathrm{g}) .
\end{aligned}
$$

\section{RESULTS AND DISCUSSION}

Results

\section{Genetic Variation and Population Structure of Bigeye Tuna}

The $D$-Loop mtDNA amplification of the fish using primer Pro-5 and primer 12SAR was noted as CAC GAC GTT GTAAAA CGA CCT ACC YCY AAC TCC CAA AGC and GGA TAA CAA TTT CAC ACA GGG

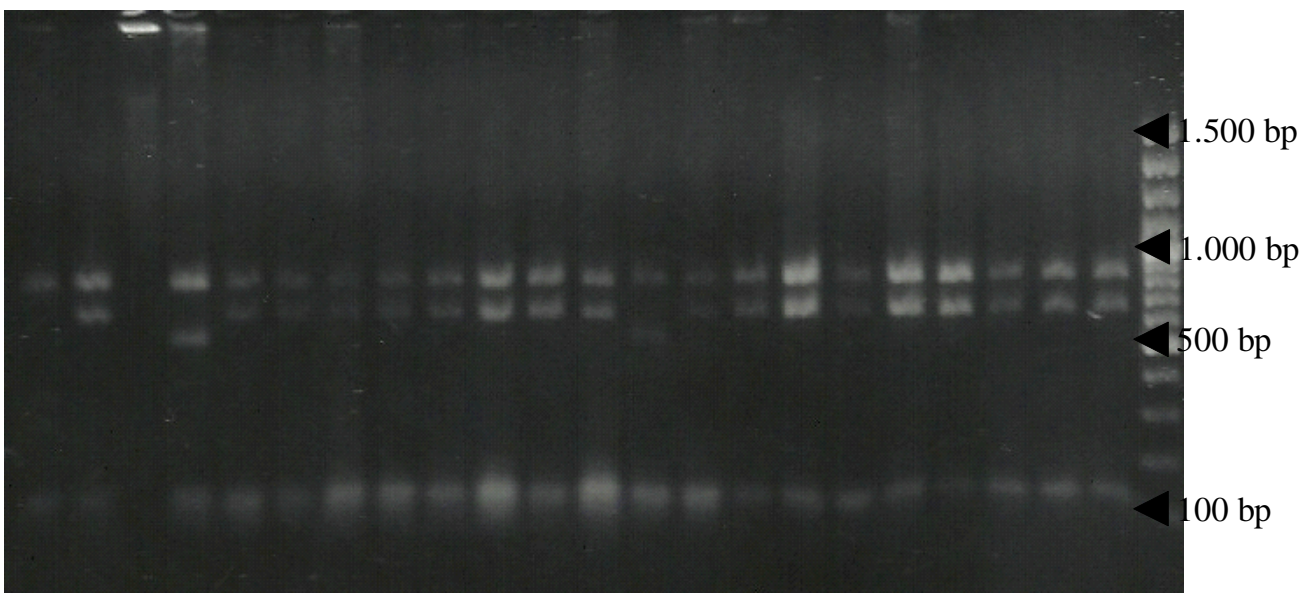

Figure 1. Single fragment of mtDNA tested by PCR amplification of bigeye tuna (Thunnus obesus) in Indian Ocean.

CAT AGT GGG GTA TCT AAT CC ranged $1.500 \mathrm{bp}$ (base pairs) in all groups of sample (Figure 1).

Diversity number and size of restriction fragment (RFLP) obtained from mtDNA restriction using four enzymes were 12 types of restriction. Taq / with six types of restriction A, B, C, D, E, and F, Hin6 / with one type of restriction A, Mbo I with two types of restriction $A$, and $B$, and Rsa I with three types of restriction $A, B$, and $C$.

\section{Haplotype Variation}

The restriction enzymes detected 12 composites of haplotype mt DNA D-Loop in which 10 composites of them were located in group I. Another eight composites were in group II (Table 2).

Composite haplotype AAAA, AAAB, AAAC, $A A C A, A B A B$ and $A A A D$ were spread to all groups. All six composite haplotypes were catogorized as major composite haplotypes because they were exist in all group. Composite haplotype AABA, AACB, AABB and $A B A A$ were only distributed in group I while composite haplotype AAAE and AAAF were only found in group II. These six composite haplotypes were categorized as common haplotype because they were only recorded in each group. In addition, composite haplotipe $A A A B$ was the highest composite haplotype found in group II and group I as much as $36 \%$ and $29 \%$ respectively.

In contrast, composite haplotype AAAA was identified in group II and group I as much as $29 \%$ and $26 \%$ respectively. The haplotype variation of group I and group II was 0.7766 and 0.8267 respectively with an average of 0.8017 (Table2).

Mark of haplotype diversity of group I and group II was 0.7766 and 0.8267 respectively with an average of 0.8017 (Table 2).

\section{Genetic Distance}

Based on comparison test of Fst among groups using TFPGA program, it is found that there was significantly different between group I and group II (Table 3).

Genetic relationship among groups of bigeye tuna samples in the Indian Ocean was 0.0038 (Table 4 and Figure 2). 
Table 2. Haplotype frequency of mt-DNA $D$-loop region of bigeye tuna in Indian Ocean restricted using four enzymes Taq I, Hin6 I, Mbo I and Rsa I.

\begin{tabular}{cccc}
\hline & & \multicolumn{2}{c}{ Frequency (\%) } \\
\cline { 3 - 4 } No & Type of composite haplotype & Group II \\
\cline { 3 - 4 } & & Group I & 0.29 \\
2 & AAAA & 0.26 & - \\
3 & AABA & 0.08 & 0.36 \\
4 & AAAB & 0.29 & 0.04 \\
5 & AAAC & 0.03 & 0.04 \\
6 & AACA & 0.03 & - \\
7 & AACB & 0.03 & 0.11 \\
8 & AABB & 0.10 & - \\
9 & ABAB & 0.05 & 0.11 \\
10 & ABAA & 0.05 & 0.04 \\
11 & AAAD & 0.08 & 0.04 \\
12 & AAAE & - & 8 \\
\hline & AAAF & - & 0.7766 \\
\hline
\end{tabular}

Table 3. Pair test (Fst) among group of sample of bigeye tuna in Indian Ocean.

\begin{tabular}{ccc}
\hline & Group I & Group II \\
\hline Group I & xxxxxxxxx & $0.0212^{*}$ \\
Group II & & xxxxxxxx \\
\hline
\end{tabular}

Note : ${ }^{*}=$ Significantly different with $\mathrm{p}<0.05$

Table 4. Genetic relationship among group of samples (phylogeny) of bigeye tuna in Indian Ocean

\begin{tabular}{ccc}
\hline & Group I & Group II \\
\hline Group I & $x x x x x x x x x$ & 0,0038 \\
Group II & & $x x x x x x x x x$ \\
\hline
\end{tabular}
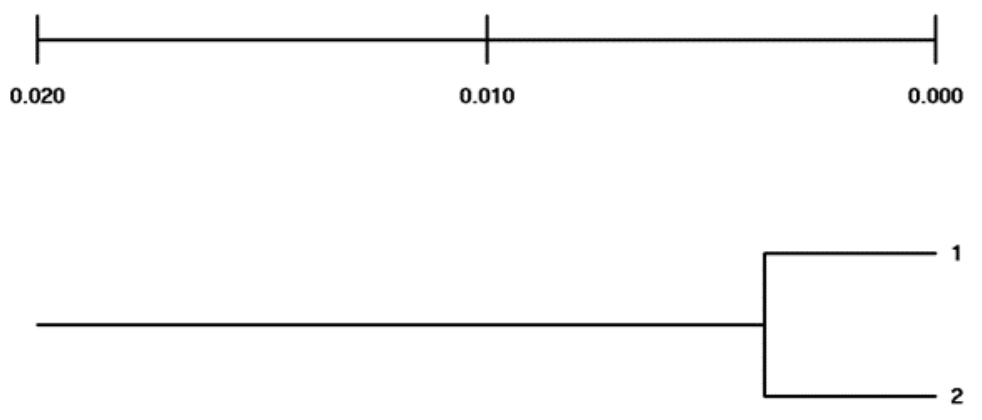

Figure 2. Dendrogram of genetic relationship (phylogeny) of two different population of bigeye tuna in Indian Ocean.

\section{Population Structure}

Dendrogram clustered two different sub populations. The first was south off Java and Nusa Tenggara and the second was west off Sumatera.

\section{Gonade Maturity Level}

Based on histology analyses, the fish were dominated by the maturity of level I accounted for $39 \%$. This was followed respectively by level II (21\%), III (17\%), IV (11\%). VI (5\%), VII (4\%), and V (3\%) (Figure 3). 


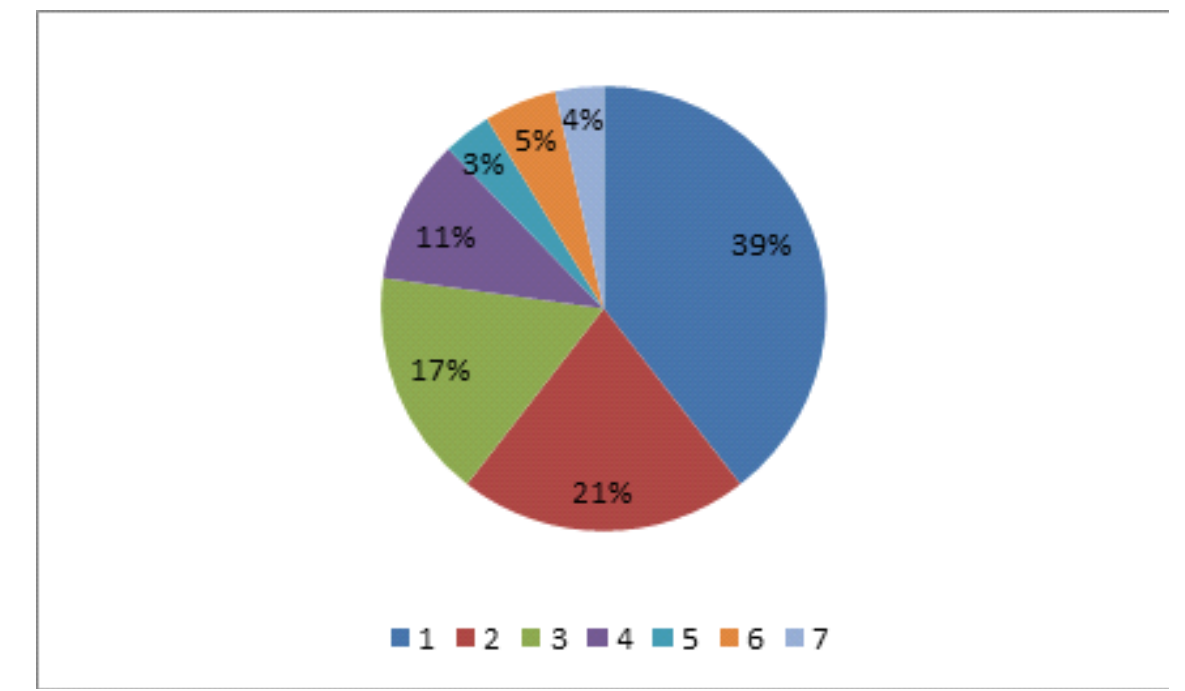

Figure 3. Percentage of gonade maturity level of bigeye tuna in Indian Ocean based on histologal identification.

In order to predict their spawning season, level of gonade maturity must be compared to time of sampling. Figure 3 illustrated that the percentage of each level is increased. The fish with gonade maturity level I from April to October is increased from $4.4 \%$ to $77.8 \%$. Level II was found in April and October with frequency of $8.3 \%$ and $91.7 \%$, while the fish in level III was caught in June and October with frequency of $5.3 \%$ and $94.7 \%$. In contrast, level IV and level VII were only recorded in October and March respectively. In addition, the fish both level V and level VI were found in March, April, and October.

According to class of length, level I was found almost in all class of length except class 155-160 $\mathrm{cm}$. In addition, the fish in level I was dominantly found in class $131-140 \mathrm{~cm}$. On the other hand, level II had interval length of $91-150 \mathrm{~cm}$ and mostly found in class $101-110 \mathrm{~cm}, 121-130 \mathrm{~cm}$, and $141-150 \mathrm{~cm}$. The fish with level III was identified in length of class $91-100$ $\mathrm{cm}$ and $111-150 \mathrm{~cm}$ with the highest percentage in class $131-140 \mathrm{~cm}$. Level IV was distributed in interval $101-150 \mathrm{~cm}$ with the highest percentage in class 111 $120 \mathrm{~cm}$. Different shape was shown by the gonade maturity of level $\mathrm{V}$. The fish in this level was only found in class interval $111-120 \mathrm{~cm}$ and $131-140 \mathrm{~cm}$ with the highest percentage in the later interval. Last but not least, level VI had three class intervals, namely 91 $100 \mathrm{~cm}, 121-130 \mathrm{~cm}$, and $151-170 \mathrm{~cm}$ with the highest percentage in the middle interval. Finally, gonade maturity of level VII was only found in class interval $121-140 \mathrm{~cm}$ with the highest percentage in interval $121-130 \mathrm{~cm}$.

Figure 4 illustrated that bigeye tunas in maturity of level I-III were caught in south off Java and Bali. While the fishes in maturity of level IV-VII were found in south off Nusa Tenggara. However the fishes in maturity of level III-V were also recorded in south of Java and Bali and the fish in maturity level II was identified in south off Nusa Tenggara.

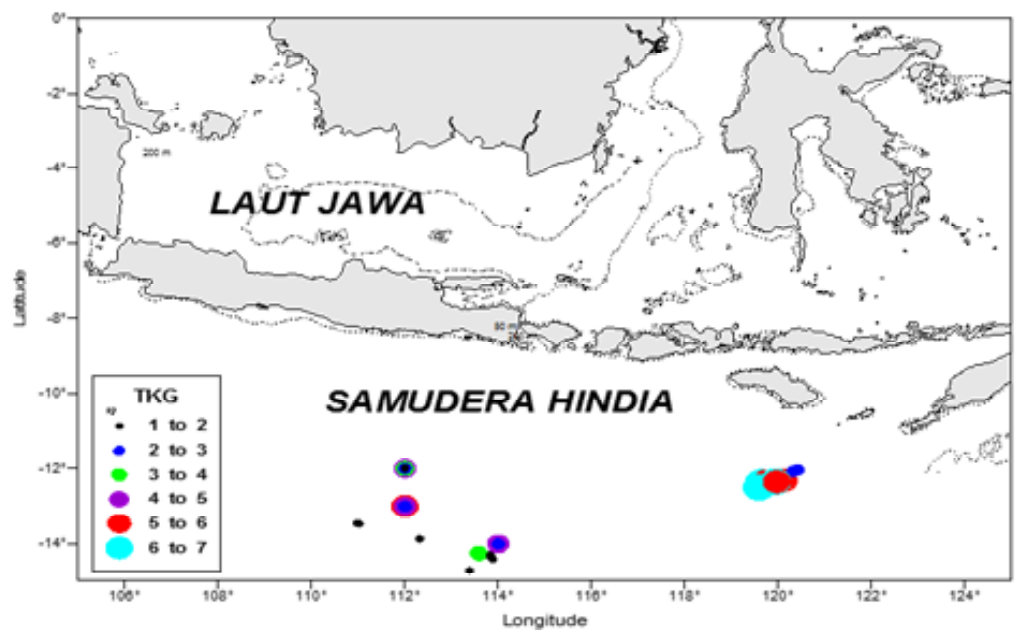

Figure 4. Fishing ground of each maturity level of bigeye tuna in Indian Ocean. 


\section{Gonada Somatic Index (GSI)}

In general, GSI is increased and reached the peak when the fish spawned. GSI in March was 2.78 and is decreased to 0.44 during April to June. In addition, the mark was going to increase to 0.47 and 0.86 in July and October respectively.

Trend of GSI was in line with maturity level of the fish. In maturity level I, the GSI was very low (0.51). While in maturity level II the GSI is increased to 0.71 . The GSI continued to increase in maturity level III, IV, $\mathrm{V}, \mathrm{VI}$, and reached the peak to be 3.19 in maturity of level VII.

\section{Discussion}

Haplotype differences among and intra population were caused by changed, additional, and absence of certain chemical notation of $D$-Loop region mtDNA so that certain enzyme did not cut in the same location. This condition could cause the move of haplotype which indicated better genetic variation among and intra population.

Genetic variation shown by number of haplotype of the bigeye in group I (0.8267) and group II (0.7766) was equal with number of haplotype in other fish which accounted for 6 to 17 with diversity mark from 0.6 to 0.9 (Nugroho, 2001). Meanwhile Bremer et al. (1998) found that the bigeye in Atlantic Ocean, Indian Ocean, and Pacific Ocean had 13 composite haplotypes. Yet in Indian Ocean itself, the fish have about five haplotype composite.

Average mark of genetic diversity was 0.8017 . This was a bit lower than average mark of yellowfin tuna, 0.857 (Permana et al., 2007) but a bit higher than other fast swimmer fish such as shark (0.64). (Heist, 1999 cited by Permana et al., 2007). Graves \& McDowell (1994) cited by Tabata et al. (1997) illustrated that overall mark of haplotype diversity of all mtDNA of stripead marlin was 0.82 . While Avise et al., (1989) cited by Tabata et al. (1997) added that haplotype diversity of all mtDNA of several fish ranged from 0.473 to 0.998 .

This high mark of haplotype diversity indicates that the bigeye tuna population in the Indian Ocean especially group of sample I in south off Java and Nusa Tenggara is categorized as low disturbance stock. It also informes that the stock had higher level of migration habit than other species so that the stock had high chance to get cross spawning with other stocks (Wild, 1994 cited by Permana et al., 2007). In contrast, the fish in west off Sumatera with lower mark of haplotype diversity (0.7766) indicated that the stock had smaller size than another. Leary et al. (1985) cited by Ayu (2005) stated that lower mark of genetic diversity would cause negative impact such as the decrease of growth, size diversity, organ development stability, degree of life, and environment adaptation.

Genetic gap among bigeye population in Indian Ocean was only 0.0038 . The lower the mark of genetic gap the closer the fish diversity will be and vice versa. The bigeye tuna in sample I (south off Java and Nusa Tenggara) had very low mark of genetic gap with the fish in sample II (west off Sumatera) (Table 4 and Figure 5). This phenomenon shows the closer relationship between them. It is predicted that fishing ground of both samples should be not separated each other. Therefore migration and genetic change between them are often taken place. In addition, the bigeye tuna had relatively equal mark of genetic gap with fish from same sub species such as king fish (Nugroho et al., 2001). Dendrogram based on genetic diversity illustrates that the stock of bigeye tuna in the Indian Ocean consisted of two sub populations, namely south off Java and Nusa Tenggara and west off Sumatra.

The occurrence of two different sub populations of bigeye tuna in Indian Ocean was predicted to be caused by the difference of original region of both sub populations where they come from, namely Pacific Ocean and Indian Ocean. Sub population in west of Sumatera may have been the original stock while sub population in south off Java and Nusa Tenggara may have come from Pacific Ocean. Suda (1971) cited by Sumadhiharga (2001) stated that bigeye tuna from Pacific Ocean often migrated to the Indian Ocean through the Philippines and Indonesia waters.

Analysis toward both sub populations showed that they had high mark of genetic diversity. This indicates that the stock did not get too much disturbance. Better management is needed in order to keep the stock away from any disturbance so that the decrease of genetic diversity can be avoided.

The size of bigeye tuna ranged from 60 to $177 \mathrm{~cm}$ with modus in interval $90-99 \mathrm{~cm}$. Most of samples (about 90\%) were categorized as matured fish. Nootmorn (2004) reported that size at first maturity of bigeye tuna in the Indian Ocean for female and male was $88.08 \mathrm{~cm}$ and $86.85 \mathrm{~cm}$ respectively.

Gonade maturity is the most important stage in development of fish. During reproduction, most energy is spent to develop gonade in maturity stage. Weight of gonade will reach maximum just before fish get to 
spawn and then the weight will go down quickly during spawning process until finish. Effendie (1997) stated that gonade weight for female and male could reach $10-25 \%$ and $5-10 \%$ of body weight respectively. He added that the higher the level of gonade maturity, the bigger the egg in gonade would be. Kuo et al., (1973) emphasized that level of gonade maturity was indicated by development of average diameter of egg and distribution type of egg size.

Based on gonade maturity level and size length of class informed that length of fish in maturity IV to VII ranged from $91 \mathrm{~cm}$ to $170 \mathrm{~cm}$. Previous research stated that size of fish at first maturity $(\mathrm{Lm})$ of big eye tuna in Indian Ocean was $88.08 \mathrm{~cm}$ (Nootmorn , 2004) and $102.4 \mathrm{~cm}$ (Farley et al., 2003). Another research informed that size of fish at first maturity of big eye tuna in Pacific Ocean was 91-100 cm in length and $14-20 \mathrm{~kg}$ in weight (Yuen, 1955). Sun et al. (2006) added that bigeye tuna in Pacific Ocean already matured as long as $99.7 \mathrm{~cm}$.

Average mark of GSI went down from March to June. Relationship between gonade maturity level and GSI showed that average mark of GSI increased in line with the increase of gonade maturity level. Effendi (1997) stated that comparison between body weight and gonade weight increased due to higher level of gonade maturity level. Mark of GSI of bigeye tuna is varied in the Indian Ocean during March to October . The highest mark is obtained in March. This means that the fish spawned before March. Nootmorn (2004) who found that spawning activity of fish in east part of Indian Ocean occured in December, January, and June gave different opinion. In east part of Pacific Ocean, spawning activity of fish was taken place during April to September in north latitude and during January to March in south latitude. Zhu et al. (2010) added that the spawning activity of bigeye in eastern and central tropical Pacific Ocean occured between March and November.

Different research result obtained compared to previous research was due to incomplete data obtained in the current work. The assessment of the research did not conduct all the year so that data about peak of spawning season was not collected. Another reason as stated by Nishikawa (1985), in around equator of Atlantic, Indian, and Pacific Oceans the fish spawned during the year. Sun et al. (2006) added that bigeye tuna in east part of Pacific Ocean had spawning activity during April to September, January to March, and October to January.

\section{CONCLUSION}

The population structure of bigeye tuna in the Indian Ocean consisted of two different sub populations, namely west off Sumatera and south of Java and Nusa Tenggara. The sub population found in south off Java and Nusa Tenggara is presummed to come from Pacific Ocean, while that in west off Sumatera is the original stock of Indian Ocean.

Analisys of reproductive biology brought some information, as follow: (i) the gonade maturity level I $(39 \%)$ is the dominant reproductive condition in bigeye tuna; (ii) the fish likely spawns during all the year; and (ii) south off Java-Nusa Tenggara is a spawning ground of big eye tuna.

\section{ACKNOWLEDGEMENTS}

This paper was part of the Inhouse program titled the study of genetic diversity and reproductive biology of large pelagic fish (bigeye tuna, Thunnus obesus, Family Scombridae) in Indian Ocean, F.Y. 2010.

\section{REFERENCES}

Ayu, H.S. 2005. Genetic diversity evaluation of four population of nile tilapia (Oreochromis niloticus) based on mtDNA D-loop analysis[skripsi]. Fisheries Department, Faculty of Fisheries. Juanda University. Bogor.

Bremer, J.R.A., B. Stequert, N.W. Robertson \& B. Ely, 1998. Genetic evidence for inter-oceanic subdivision of bigeye tuna (Thunnus obesus) populations. Marine Biology 132: 547-557.

Effendie, M.I. 1997. (In Indonesian). Fisheries Biology. Yayasan Pustaka Nusantara.

Farley, J., N. Clear, B. Leroy, T. Davis \& G. Mcpherson, 2003. Age and growth of bigeye tuna (Thunnus obesus) from the eastern and western AFZ. Report No. 2000/100. CSIRO Marine Research. Australia. 93 pp.

Kuo, C.M., Z.H. Shehadeh \& K.K. Milisen, 1973. A preliminary report on the development, growth and survival of laboratory reared larvae of the grey mullet, Mugil cephalus L.J. Fish. Biol., 5: 459-470.

Miller, M.P. 1997. Tools for population genetic analyses (TFPGA) version 1.3. Department of Biological Sciences-Box 5640. Northern Arizona University. 
Nei, M. 1972. Genetic distance between populations. American Nature 106: 283-292.

Nei, M. 1978. Molecular evolutionary genetics. Columbia University Press, New York.

Nishikawa, Y., M. Honma, S. Ueyanagi \& S. Kikawa, 1985. Average distribution of larvae of oceanic species of Scombroid fishes, 1956-1981. S Ser.Far Seas Fish.Res.Lab., (12): 99 pp.

Nootmorn, P. 2004. Reproductive biology of bigeye tuna in the eastern Indian Ocean. Document IOTC2004-WPTT-05, presented at the Working Party on Tropical Tunas, Victoria, Seychelles, July 13th$20^{\text {th }} 2004$

Nugroho, E., D.J. Ferrel, P. Smith \& N. Taniguchi, 2001. Genetic divergence of Kingfish from Japan, Australia and New Zealand Inferred by microsatellite DNA and mitochondrial DNA control region markers. Journal Fisheries Science 67: 843-850.

Permana, G.N., J.H. Hutapea, Haryanti \& S.B.M. Sembiring. 2007. Genetic variety yellow fin tuna (Thunnus albacares) using electrophoresis allozyme and mt-DNA analysis. Aquaculture Research Journal 2 (1): 41-50.
Sumadhiharga, K. 2001. Tuna fishery in Indonesia. Paper presented in Innaguaration of Primary Research Expert of Marine Biology in Oseanography Research Center Science Research Board of Indonesia, 6th September 2001.

Sun, C.L., S.L.Chu \& S.Z.Yeh. 2006. The Reproductive biology of female bigeye tuna (Thunnus obesus) in the Western Pacific. Scientific Committee Second Regular Session. Manila, Philippines. 22 pp.

Tabata, K. \& A. Mizuta. 1997. RFLP analysis of the mtDNA D-loop region in red sea bream, Pagrus major population from four locations of western Japan. Journal Fisheries Science 63 (2): 211-217.

Yuen, H.S.H. 1955. Maturity and fecundity of bigeye tuna in The Pacific. U.S. Fish Wildl. Serv., Spec.Sci.Rept.Fish., 150: 30 pp.

Zhu,G., X.Dai, L. Xu \& Y. Zhou, 2010. Reproductive biology of bigeye tuna, Thunnus obesus, (Scombridae) in the eastern and central Pacific Ocean. Environ. Biol. Fish, p. 1-8 . 